\section{The Canadian Journal of Higher Education/La Revue canadienne d'enseignement supérieur}

\author{
Michelle Pidgeon \\ Simon Fraser University \\ Ashley Pullman \\ University of Ottawa \\ Walter Archer \\ University of Alberta \\ Amélie Groleau \\ McGill University
}

Scholarly and Research

Communication

VOLUME 10 / ISSUE 2 / 2019

\begin{abstract}
The Canadian Journal of Higher Education (CJHE) has been the sole journal for higher education scholarship in Canada for over 40 years, and is the primary source of commentary on trends and relevant research in the Canadian postsecondary context. Since its inauguration in 1971, the CJHE has promoted both English- and Frenchlanguage higher education research, and the shift from a print to open access journal in 2009 further promoted the accessibility of this scholarship. Along with documenting the success and growth of the CJHE, this article highlights ongoing production challenges and the need to support greater diversity in regard to language, themes, and authorship. It concludes by presenting a vision plan for the future - an articulation of hopes for the field of higher education in Canada.
\end{abstract}

Keywords Higher education; Canada; Postsecondary education; Research; Open access publication

\section{Résumé}

La Revue canadienne d'enseignement supérieur (RCES) est l'unique revue savante dans le domaine de l'enseignement supérieur canadien depuis plus de 40 ans en plus dêtre la principale source analyse de tendances et de recherches pertinentes dans le contexte postsecondaire canadien. Depuis son inauguration en 1971, la Revue s'est employée à promouvoir la recherche sur l'éducation supérieure en langue anglaise et française, et le passage en 2009 d'une publication papier à une publication en libre accès a contribué encore davantage à l'accessibilité de ce domaine de connaissances. En plus de

\section{CISP Press}

Scholarly and Research Communication

Volume 10, Issue 2, Article ID 1002305, 12 pages

Journal URL: www.src-online.ca http://doi.org/10.22230/src.2019v1on2a305

Received September 7, 2018, Accepted December 30, 2018, Published February 22, 2019

Pidgeon, Michelle, Pullman, Ashley, Archer, Walter, \& Groleau, Amélie. (2019). The Canadian Journal of Higher Education/La Revue canadienne d'enseignement supérieur. Scholarly and Research

Communication, 10(2): 1002305, $12 \mathrm{pp}$.

(C) 2019 Michelle Pidgeon, Ashley Pullman, Walter Archer, \& Amélie Groleau. This Open Access article is distributed under the terms of the Creative Commons Attribution Non-Commercial License (http://creativecommons.org/licenses/by-nc-nd/2.5/ca), which permits unrestricted non-commercial use, distribution, and reproduction in any medium, provided the original work is properly cited.
Michelle Pidgeon is an Associate Professor and Director of the Centre of Educational Leadership and Policy Studies in the Faculty of Education, Simon Fraser University. She served as Editor for the Canadian Journal of Higher Education from October 2015 to January 2019. Email: michelle_ pidgeon@sfu.ca

Ashley Pullman is currently a SSHRC-funded Postdoctoral Fellow at the Education Policy Research Initiative (EPRI) in the Graduate School of Public and International Affairs, University of Ottawa and the Journal Manager for the Canadian Journal of Higher Education. Email:

apullman@irpe-epri.ca

Walter Archer is Professor Emeritus at the University of Alberta and the Book Review Editor of the Canadian Journal of Higher Education. Email: warcher@ualberta.ca 


\section{Scholarly and Research}

\section{Communication}

VOLUME 10 / ISSUE 2 / 2019

Amélie Groleau pursued a postdoctoral fellowship at the Centre on Population Dynamics (McGill University, Canada) from 2016 to 2018.

She has been serving as

French Editor for the

Canadian Journal of Higher

Education since January 2016.

Email: amelie.groleau@mail

.mcgill.ca documenter le succès et l'essor de la Revue canadienne d'enseignement supérieur, nous soulignons les défis de production actuels ainsi que la nécessité de soutenir une plus grande diversité en ce qui a trait à la langue de publication, aux thèmes des articles et aux auteurs potentiels. Nous concluons en présentant la notre plan d'avenir qui articule nos espoirs concernant le champ de l'enseignement supérieur au Canada.

Mots Clés Enseignement supérieur; Canada; Education postsecondaire; Recherche; Publication en libre accès

\section{Introduction}

Canadian higher education, which remains under provincial and territorial jurisdiction, began with the establishment of early universities, such as Université Laval (established in 1663) and the University of New Brunswick (established in 1785) (Jones, 2012). Over time, the postsecondary systems in each province and territory evolved to include universities, polytechnics, community colleges, and institutes. According to Employment and Social Development Canada (2017), over 80 universities, approximately 130 community colleges, two polytechniques, and five institutes make up the public postsecondary system in Canada (excluding CEGEPs in Québec). ${ }^{1}$ Although higher education remains a predominantly public system, some provinces allow for private institutions to operate under their scrutiny.

Concurrent with the rapid expansion of the postsecondary sector in Canada, higher education became a recognized field of study in the mid-1960s. The field was formally organized in 1970 with the formation of the Canadian Society for the Study of Higher Education (CSSHE), which emerged from a higher education research group at the University of Toronto (Jones, 2012). Under the direction of Edward Sheffield (1961), best known for the 1955 Sheffield Report predicting the massification of higher education, the CSSHE founded the Canadian Journal of Higher Education/La Revue canadienne denseignement supérieur (CJHE/RCES). The inaugural issue of the CJHE/RCES in 1971 was under the editorship of Edward Joseph Monahan (English editor) and André Girard (French editor), and both the organization and journal have been the pulse of Canadian higher education scholarship ever since.

Over the last 40 years, the University of Toronto, the University of Calgary, the University of Alberta, Memorial University, Western University, Royal Roads University, the University of British Columbia, and Simon Fraser University grew their higher education programs in response to the growing demand for practitioners, leaders, and scholars in this sector (Jones, 2012). Within the higher education landscape, both nationally and internationally, the CJHE/RCES has also contributed to the development of policy and research agendas specifically for Canadian research related to higher education.

This article traces the development of the CJHE/RCES and highlights notable shifts in readership, submissions, and focus. After describing the history of the journal, we discuss the nature of our current operations and ongoing challenges (e.g., limited funding, increases in copy-editing and production costs, difficulty in obtaining timely reviews). Additionally, we highlight our current goal of promoting emerging and French scholarship. We then present our vision plan for the future, including, notably, increasing read-

Pidgeon, Michelle, Pullman, Ashley, Archer, Walter, \& Groleau, Amélie. (2019). The Canadian Journal of Higher Education/La Revue canadienne d'enseignement supérieur. Scholarly and Research Communication, 10(2): 1002305, 12 pp. 
ership and the promotion of open access scholarship and thereby strengthening the field of higher education in Canada.

\section{The history of the CJHE/RCES}

Founded in 1971 by the CSSHE, the CJHE/RCES has been, from its beginning, a bilingual peer-reviewed publication. The founding aims were " 1 ) to encourage independent and critical study of the issues and problems in post-secondary education in Canada; and 2) collect and disseminate information about these activities" (Pascal, 2011, p. iii). Today, the journal's primary focus aligns with these aims; that is, it publishes researchbased manuscripts on topics that address and are relevant to the Canadian higher education system and its structures, processes, and diverse communities. The journal also promotes Canadian-based and international comparative research relating directly to the Canadian higher education context. As stated in the inaugural issue, CJHE/RCES intends to provide a "Canadian forum specially devoted to the publication of the results of scholarly research and reflection on higher education in Canada" (Monahan, 1971, p. 3).

Edward Sheffield and Robin Harris, who initiated the Higher Education Group at the Ontario Institute for Studies in Education (Jones, 2012; Pascal, 2011), influenced the establishment of the CJHE/RCES. Also influential was the increasing number of higher education administrative personnel who were employed in service units supporting higher education teaching and academic programs offering specialized training in higher education research and scholarship. As Charles Pascal (2011) writes, "cropping up at the time were 'pedagogical service units' including the newly established Centre for Learning and Development at McGill University, the Institute for Research in Human Abilities at Memorial University, and the Study Group for Educational Methods at Nova Scotia Technical College" (p. ii). Thus, unlike many other scholarly associations in Canada and abroad, CSSHE members included both scholars and practitioners. Higher education scholarship was deemed to be interdisciplinary in focus and to necessarily engage with national voluntary associations (Pascal, 2011), such as Universities Canada, Canadian Association of College and University Student Services (CACUSS), and the Canadian Association of University Teachers (CAUT).

Since its inauguration, several important changes have taken place. Over time, Robin Ross, Daniel W. Lang, Charles Belanger, Ronald Duhamel, Alexander Gregor, Lise Tremblay, Alice Boberg, Glen A. Jones, Michael Skolnik, Jamie Magnusson, Esther Enns, Lynn Bosetti, Keith Archer, Lesley Andres, and Michelle Pidgeon have fulfilled the editor-in-chief role. Among these editors were researchers, administrators, and scholars within political science, higher education, and education. In fact, prior to and after their terms as editors, many of these scholars remained active contributors to the journal. Each editor contributed leadership and vision to building capacity across the field and also to the legacy of higher education in the country. The number of annual issues shifted from two to three in 1975 and from three to four in 2005; however, financial turbulence has generated occasional inconsistency in the number of articles and issues published.

Financing has been a continual point of concern for the journal. Early in the history of the CJHE, Past President of CSSHE Lucien F. Michaud's 1973 editorial stated that

Pidgeon, Michelle, Pullman, Ashley, Archer, Walter, \& Groleau, Amélie. (2019). The Canadian Journal of Higher Education/La Revue canadienne d'enseignement supérieur. Scholarly and Research Communication, 10(2): 1002305, 12 pp. 


\section{Scholarly and Research}

Communication

VOLUME 10 / ISSUE 2 / 2019 "financial resources have been meagre and still continue to be so" (p. 4). During that period, the journal was primarily supported through revenue generated by CSSHE memberships and conferences, and then later through the Aid to Scholarly Journals fund from the Social Sciences and Humanities Research Council (SSHRC). Moving from a print-only publication to a print/online journal and now being solely an online publication has addressed some financial concerns; however, even with the move to online there are still the costs of running any academic journal (e.g., copy-editing, production layout, journal management). Today, the main financing comes from SSHRC's Aid to Scholarly Journals fund, which is an important financial support for many scholarly journals in Canada. The CJHE editor, with the support of the journal manager in partnership with the CSSHE secretariat, applies to this fund every three years. In addition to this financial support, the editorial management of a scholarly journal does rely extensively on volunteers (e.g., editor, editorial board members, and reviewers) to operate and uphold the academic integrity of the peer-review process. Peer-reviewed scholarship is a core academic value that the journal remains committed to upholding. The journal is committed to ensuring it remains open access for both readers and authors; hence it does not charge authors article-processing fees.

\section{The History of English-language SCHOlarship in CJHE/RCES} In the 1970s, the journal focused on establishing the Canadian field of higher education not only through publishing academically focused English-language articles but yearly bibliographies of recently published books, articles, reports, and university and governmental documentation. One of the last bibliographies, published in 1978, documents contributions in seven key areas: history and organization; curriculum and teaching; current trends and problems; research and scholarship; the student and student services; the professor and conditions of work; and non-degree granting institutions. The divide between scholarship focusing on degree-granting and non-degreegranting institutions is notable. Indeed, John Dennison suggested there was a "need for a broader view that examined the role of colleges and other training institutions [as] early on, the Society had a somewhat narrower bent on planning and financing in universities" (quoted in Pascal, 2011, p. iii).

In the 1980 s and 1990s, emphasis was placed on editorials and social commentary and increasing the number of published articles. Along with academics, many government officials and university administrators wrote editorials; for example, David E. Allnutt (1985), co-founder and vice chairman of the Corporate-Higher Education Forum, discussed higher education-industry partnerships; Sheryl L. Bond (1987), director of the Office of Higher Education Management at the University of Manitoba, discussed employment equality; and Peter Ferris (1989), member of the Post-Secondary Career Development Branch within the Province of Manitoba, wrote about postsecondary education in northern Canada. Although the last editorial was written in 1991, during the 1990 commentary began to shift toward critique, such as Scott Carson's (1999) response to Peter Emberley's book Zero Tolerance: Hot Button Politics in Canada's Universities and Samad, Fraser, Fish, and Fraser's (1995) assessment of the Smith Commission Report. The move away from essays marks a notable shift. As Glen Jones recalls, "over time the Journal became more open to different methodological approaches going from the kind of essays that marked its earlier years" (quoted in Pascal, 2011, p. iv).

Pidgeon, Michelle, Pullman, Ashley, Archer, Walter, \& Groleau, Amélie. (2019). The Canadian Journal of Higher Education/La Revue canadienne d'enseignement supérieur. Scholarly and Research Communication, 10(2): 1002305, 12 pp. 
In the 2000s and 2010s, a number of important shifts took place. As illustrated in Figure 1, the number of published manuscripts increased in the 1990s, an expansion that continued into the late $2010 \mathrm{~s}$ and mirrored the growth in academic output experienced by many journals during this time (Larivière, Haustein, \& Mongeon, 2015). Although there were few special issues prior to the late 2000s, they became more frequent after this point, starting with an issue titled "Open Access: An Old tradition and a New Technology" in 2009. Special issues continued on a regular basis and included "Using Social Statistics to Illuminate the Issues, Processes, and Outcomes in Higher Education" in 2010; "Liberal Arts: Looking Back and Moving Forward" in 2012; "Blended and Online Higher Education: Teaching and Learning in a Wired World" in 2013; "Preparing Graduate Students for a Changing World of Work" in 2014; "Quality Enhancement: Teaching Preparation for Graduate Teaching Assistants" in 2015; and "Governance in Higher Education" in 2016.

\section{Figure 1: The cumulative publication rate of French- and English-language articles in the CJHE/RCES}

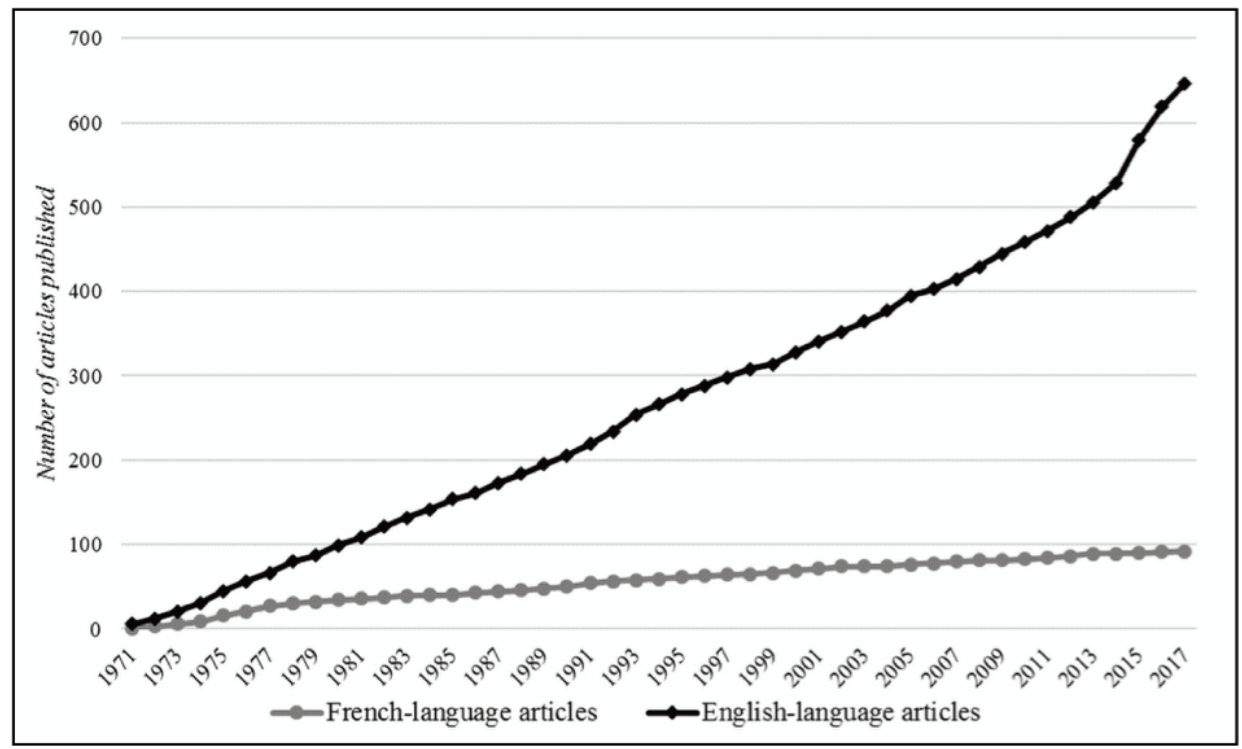

Note: Rates of published articles include special edition articles, but exclude non-peer reviewed publications, such as book reviews, editorials, and commentaries.

\section{THE HISTORY OF FRENCH-LANGUAGE SCHOLARSHIP IN CJHE/RCES}

From the very beginning, the CJHE/RCES has been dedicated to publishing work from French scholars. In its first decade of existence, the journal featured at least one French manuscript in each issue; the volume of publications from French authors was especially prominent in the mid-1970s. Similar to English-language publications during this period, French contributions came from various stakeholders in higher education, including scholars, university administrators, and senior civil servants. Authors tackled different issues, including those raised by the increased demand for higher education, the funding of postsecondary institutions and research programs, and the evolution of the educational system. Most French-language articles focused on the Québec educa-

Pidgeon, Michelle, Pullman, Ashley, Archer, Walter, \& Groleau, Amélie. (2019). The Canadian Journal of Higher Education/La Revue canadienne d'enseignement supérieur. Scholarly and Research Communication, 10(2): 1002305, $12 \mathrm{pp}$. 


\section{Scholarly and Research}

\section{Communication}

VOLUME 10 / ISSUE 2 / 2019 tional context, which had undergone important changes in the 196os due to what is often referred to as "the Quiet Revolution."

French contributions changed in the 1980 s and then even more in the 1990 . Mirroring the evolution of English-language publications, manuscripts became more academically oriented. Research and funding were still discussed, but new topics emerged in relation to academic fields close to the study of higher education, such as education administration, program evaluation, and postsecondary pedagogy. The CJHE/RCES also published scholarship addressing social issues, such as demographic changes in the university student body (e.g., older adult and linguistic minorities), the employment of postsecondary graduates, and the characteristics of faculty members.

Since 2000, the shift in the French-language publication toward research-based articles has been complete. Most of the articles published in the past 15 years have been focused on student issues (e.g., access, experience, persistence, learning, and employability) and, in some cases, specific student populations (e.g., non-traditional, immigrants, minorities). Additionally, a few articles have focused on institutional and policy-level analysis. Authors are still largely affiliated with Québec universities.

Compared to the increased number of English-language articles, French-language scholarship has not experienced a spectacular growth rate over the last two decades. This trend translates into a decrease in the overall French/English publication ratio. The proportion of articles published in French was 0.25 in the 1970s, 0.13 in the 1980 os and 1990 s, 0.10 in the 2000s, and 0.07 from 2010 to 2017 . The CJHE/RCES still publishes one to two French manuscripts per year; however, increasing the dissemination of French-language Canadian research on higher education is among the journal's core commitments going forward.

\section{BOOK REVIEWS}

Of the 424 book reviews published in the CJHE/RCES over the years, $36(8 \%)$ were published in French and 388 in English. In almost all cases the review was written in the same language as the book being reviewed, although there were two instances of a French-language book reviewed in English, and one of an English-language book reviewed in French. As is the case with peer-reviewed articles, the proportion of book reviews published in French has declined dramatically over the decades: in the 1970s, 31 percent of the book reviews published were in French, declining to 15 percent in the 1980 s, 2 percent in the 1990s, o percent in the 2000s, and 1 percent in the 2010 (the one instance of an English-language book reviewed in French).

\section{Highlights, achievements, and key influencers and subjects}

\section{THE SHIFT TO OPEN SOURCE}

In 2009, the CJHE/RCES transitioned from a subscription-based to an open source journal that provides free and accessible scholarship through the Public Knowledge Platform. Moving to this platform removed academic subscription fees, which are a major cost for postsecondary institutions in Canada and limited access to research published in the CJHE/RCES to students and staff of subscribing institutions. As an open access journal, the CJHE/RCES now has a readership that is truly public, and it is fully

Pidgeon, Michelle, Pullman, Ashley, Archer, Walter, \& Groleau, Amélie. (2019). The Canadian Journal of Higher Education/La Revue canadienne d'enseignement supérieur. Scholarly and Research Communication, 10(2): 1002305, $12 \mathrm{pp}$. 
accessible to anyone with internet access. As the Tri-Agency Open Access Policy on Publications states:

Societal advancement is made possible through widespread and barrier-free access to cutting-edge research and knowledge, enabling researchers, scholars, clinicians, policymakers, private sector and not-for-profit organizations and the public to use and build on this knowledge. (Tri-Agency, 2016, para 1)

Open source journals follow the same process for peer and editorial review as do other academic journals. Unlike fee-based journals, authors retain the copyright for their work, which enables them to freely disseminate their manuscripts.

The CJHE/RCES commemorated the shift to open source with a special issue on this topic. As shown in Table 1, two English-language publications from this issue are currently the most downloaded articles ever published in the journal. The interest in open source publications is clearly evident. As the editor in 2009, Lesley Andres (2009), wrote "our intention is to provide leadership in the field of higher education by practicing open knowledge dissemination, promoting and fostering dialogue on the topic of open access" (p. 1). The CJHE/RCES was not only one of the first education journals in Canada to switch to an open source platform but key publications in this journal have been widely disseminated.

Table 1: Top three most downloaded English- and French-language articles

\begin{tabular}{|l|l|c|}
\hline Article title & $\begin{array}{l}\text { Volume, issue } \\
\text { (year) }\end{array}$ & Downloads \\
\hline English-language & 9,500 \\
\hline $\begin{array}{l}\text { University supports for Open Access: A Canadian } \\
\text { national survey }\end{array}$ & $\begin{array}{l}\text { Vol. 29, No 3 } \\
(2009)\end{array}$ & 8,395 \\
\hline $\begin{array}{l}\text { A Matter of discipline: Open Access, the } \\
\text { Humanities, and Art History }\end{array}$ & $\begin{array}{l}\text { Vol. 39, No 3 } \\
(2009)\end{array}$ & 5,716 \\
\hline $\begin{array}{l}\text { Logistic regression analysis of graduate student } \\
\text { retention }\end{array}$ & $\begin{array}{l}\text { Vol. 23, No 2 } \\
(1993)\end{array}$ & 2,667 \\
\hline French-language & \begin{tabular}{l}
$\mid$ \\
\hline $\begin{array}{l}\text { Une enquête sur l'éthique professionnelle des } \\
\text { enseignants du collégial québécois : caractéristiques, } \\
\text { points de repère et stratégies utilisés pour traiter de } \\
\text { préoccupations éthiques }\end{array}$
\end{tabular} & $\begin{array}{l}\text { Vol. 42, No 1 } \\
(2012)\end{array}$ \\
\hline $\begin{array}{l}\text { L'intégration universitaire et sociale d'étudiants } \\
\text { tunisiens et inscrits dans une université francoph- } \\
\text { one canadienne }\end{array}$ & $\begin{array}{l}\text { Vol. 41, No 3 } \\
(2011)\end{array}$ & 2,301 \\
\hline $\begin{array}{l}\text { Le stress, les stratégies d'adaptation, le locus de con- } \\
\text { trôle et l'épuisement professionnel chez les pro- } \\
\text { fesseurs universitaires francophones }\end{array}$ & $\begin{array}{l}\text { Vol. 40, No 1 } \\
(2010)\end{array}$ & 1,841 \\
\hline
\end{tabular}

\section{KEY INFLUENCERS AND SUBJECTS}

It is necessary to highlight a number of key Canadian higher education scholars who have actively published a range of review, commentary, and articles since the journal was established. Scholars such as John Dennison (University of British Columbia), Michael Skolnik (University of Toronto), Robin Harris (University of Toronto), Robert

Pidgeon, Michelle, Pullman, Ashley, Archer, Walter, \& Groleau, Amélie. (2019). The Canadian Journal of Higher Education/La Revue canadienne d'enseignement supérieur. Scholarly and Research Communication, 10(2): 1002305, 12 pp. 


\section{Scholarly and Research}

\section{Communication}

VOLUME 10 / ISSUE 2 / 2019
M. Pike (Queen's University), Janet G. Donald (McGill University), Daniel W. Lang (University of Toronto), John S. Levin (University of California, Riverside), and Abram G. Konrad (University of Alberta) provided several contributions over the course of their careers. Compared to other disciplines, education-based scholarship has a relatively equal ratio of authorship by gender (West, Jacquet, King, Correll, \& Bergstrom, 2013); nevertheless, the editor-in-chief position was historically male dominated, especially within the earlier years (1970-1990) of the CJHE/RCES. In looking at female scholars within Canadian higher education, they too have been regularly contributing to the scholarship of the journal, such as Lesley Andres (University of British Columbia), Gwendoline Pilkington (University of Toronto), and Nancy Sheehan (University of Calgary). Gender equity issues in higher education are just as prevalent today as they were in the late 196os in this country (Henry, James, Li, Kobayashi, Smith, Ramos, \& Enakshi, 2017) and are important issues within higher education scholarship (Sheehan, 1985). The journal remains committed to ensuring the representation of gender diversity from the editor to editorial board members to reviewers to authors.

Alongside authorship, it is necessary to consider key socio-demographic concerns within CJHE/RCES articles. Higher education students are a key focus within almost all published articles. For example, among all English-language articles, 40.75 percent mention student/students, 21.94 percent mention faculty or teacher/teachers, 4.39 percent mention staff or administration, and 2.04 percent mention governance within their abstract. Depending on the group, the focus on socio-demographic characteristics also ranged. As shown in Figure 2, 9.6 percent of all published English-language articles mention gender or a related term in their abstract. Contrastingly, 4.2 percent mention class-related terms, 3.o percent mention disability and health-related terms, and 2.0 percent or less mention terms related to race, geography, or indigeneity. The journal aims to foster future scholarship that focuses on minority groups within higher education.

Figure 2: Socio-demographic focus of English-language articles

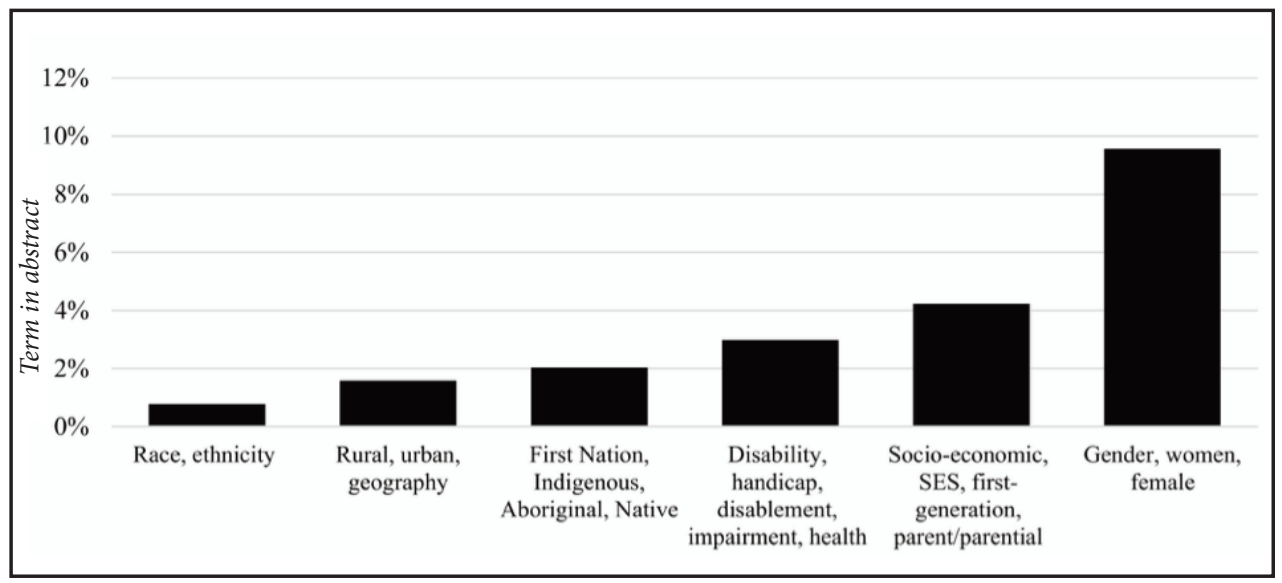

The content focus of the books reviewed in the CJHE/RCES differs significantly from that of the articles. With French-language and English-language reviews taken together, the top five content categories (with each review falling into one to three different categories) were: administration and/or governance of higher education institutions (38\%), teaching and learning (20\%), theory of higher education (18\%), history (institutions,

Pidgeon, Michelle, Pullman, Ashley, Archer, Walter, \& Groleau, Amélie. (2019). The Canadian Journal of Higher Education/La Revue canadienne d'enseignement supérieur. Scholarly and Research Communication, 10(2): 1002305, 12 pp. 
key individuals, evolution of higher education) (16\%), and internationalization (12\%).

The nature of CURRent operations: Challenges and plans The CJHE/RCES has an editorial team consisting of an editor, French editor, book review editor, production manager, and journal manager. In 2016/2017, an Editorial Advisory Board was established with representation from leading scholars in the field of Canadian higher education, both nationally and internationally. Each team member has specific roles and responsibilities. For example, the editor oversees the journal, from desk review to writing decision letters to authors to ensuring academic quality and rigour within the peer-review process. The editor is also financially responsible for the journal's operation within the funding provided by the SSHRC grant for scholarly publications. The French editor oversees any manuscripts that are submitted in French by completing a desk review of the manuscript for suitability, finding appropriate reviewers, and communicating with authors about the manuscript upon review. The book review editor is responsible for vetting appropriate books sent by publishers for suitability within the CJHE/RCES and works with book reviewers on their submissions. The journal manager works closely with the editorial team in providing administrative support in the day-to-day operations of the journal (e.g., communicating with authors, inviting reviewers to review a manuscript) to ensure the timely review of manuscripts throughout the review and production process. Upon an article's acceptance, the production manager works with the authors on matters pertaining to preparing their manuscript for publication (e.g., copy-editing, layout, and reviewing proofs).

The CJHE/RCES has an open call for submissions, with the exception of special issues (to be discussed later in this section). It is important to note that the journal publishes three issues a year, with an average of eight manuscripts per issue. The frequency of publication and number of manuscripts per issue is directly tied to funding. Funding, as it was earlier in the journal's history, remains an ongoing challenge, as there are still direct costs to operating an open access journal (e.g., production layout, copy-editing, journal management personnel). Of those costs, the most variable is the professional copy-editing of a manuscript once it has been accepted for publication. Even with an author's meticulous attention to detail, the final copy-editing does take time, and consequently financial resources, but this process ensures the academic writing standards of the journal are upheld and consistent across each issue. It is imperative that none of these costs be deferred to authors or users, as charging such fees may limit submissions rather than having the journal remain open to all those who deem it an appropriate venue for their scholarship, regardless of finances. Being fully open access is not solely for readership but also for authors themselves.

It is equally important that the journal, as a nonprofit aspect of the CSSHE, be financially responsible within its operating budget. As noted elsewhere, the primary source of funding for the CJHE/RCES is through the SSHRC publication grant, and while in $2018 / 2019$ the SSHRC has increased funding allocations in support of open access journals, the operation of the journal must still be sustainable and financially viable upon successful receipt of a such a grant. The editorial team and the CSSHE may also seek out external financial supports where appropriate. Many institutions, for example, have internal grants that the editor of a journal may be eligible to apply for to support

Pidgeon, Michelle, Pullman, Ashley, Archer, Walter, \& Groleau, Amélie. (2019). The Canadian Journal of Higher Education/La Revue canadienne d'enseignement supérieur. Scholarly and Research Communication, 10(2): 1002305, 12 pp. 


\section{Scholarly and Research}

Communication

VOLUME 10 / ISSUE 2 / 2019 specific projects. For example, during her tenure as editor, Michelle Pidgeon secured the SFU Publication Grant to support the development of a new front-facing website for the CJHE/RCES while migrating to the $\mathrm{OJS}_{3}$ platform, and the translation of all aspects of the website and communication to users to make the journal fully bilingual.

However, finances are not the only challenge in maintaining the sole publishing venue specifically dedicated to Canadian higher education - another is the quantity of submissions, which requires many dedicated volunteer hours by the editorial team and reviewers to ensure the academic quality and rigour of the scholarship published within the CJHE/RCES. On average, the journal receives 80-100 manuscripts in a given year. Since the journal has moved to online, data can be collected regarding each stage of publication. For example, over the last seven years, the average number of annual submissions received is 105, with the lowest number occurring in 2015 (77 submissions), and the highest number in 2017 (130 submissions).

The re-introduction of an Editorial Advisory Board in 2017 has helped to reduce the workload of the editorial team, as the board performs the initial review of submissions to ensure suitability. Another challenge has been ensuring that the CJHE/RCES is truly a bilingual journal, both in operations and in the representation of French-language manuscripts. The French editor plays a critical role in promoting and supporting French authors. The CJHE/RCES, with the full support of the CSSHE, continues to highly value being bilingual. Further to this, in 2017/2018, the CJHE/RCES partnered with Érudit, a French database, to support the open access dissemination of the journal to a broader audience, and, hopefully, to garner more interest from French scholars in publishing their work in the journal.

\section{Hopes and dreams for development}

Within the challenges stated above, the CJHE/RCES editorial team recognizes that the journal is also poised to take advantage of the opportunities provided by being open access.

1. As an early adopter of open source scholarship, we have a strong commitment to being publicly accessible not only for our readership but also our authors. The CJHE/RCES is committed to seeking out ways to be fiscally responsible and ensure the growth of the journal's readership. We remain committed to not charging processing or production fees to authors, and remaining the leading journal for Canadian higher education research and scholarship.

2. We are also committed to showcasing and supporting scholarship that is written in either of our official languages; specifically, we aim to increase the number of French manuscripts published in a given year. It would be aspirational but realistic to aim for one or more French-language manuscripts per issue in coming years.

3. The CJHE/RCES also hopes to partner with other higher education journals (e.g., The Journal of Higher Education in the United States, Higher Education \& Development in Australia) to build relationships and opportunities for collaboration on special issues or other research dissemination activities.

4. We will ensure that the journal provides a venue for emerging scholars to be mentored and supported through opportunities to publish and through involve-

Pidgeon, Michelle, Pullman, Ashley, Archer, Walter, \& Groleau, Amélie. (2019). The Canadian Journal of Higher Education/La Revue canadienne d'enseignement supérieur. Scholarly and Research Communication, 10(2): 1002305, 12 pp. 
ment in the journal's governance and editorial processes. Senior graduate students are asked to serve as peer reviewers on a continual basis. Additionally, prior student editors have aided in finding suitable reviewers for newly submitted manuscripts. Graduate students within Canadian higher education are the future scholars of the field, and their mentorship into the academic peer-review process of a journal such as CJHE/RCES is a critical component of developing a strong field of researchers and practitioners.

Canada's higher education system, governed by the provincial and territorial ministries, is comprised of a rich mix of institutional types (e.g., colleges, universities, polytechnics, and institutes) that serve the diversity of the Canadian population and a growing international student population. The research within this field is equally rich and provides clear insight to this system, influencing not only practice (e.g., research, teaching, administration) but also institutional, provincial/territorial, and national policy. The Canadian Journal of Higher Education is honoured to be the key journal for this scholarship and is looking forward to being part of the future of higher education in this country.

\section{Note}

1. "CEGEP" is the French acronym for a publically funded college in Québec. According to Employment and Social Development Canada (2017), CEGEPs are not counted as part of the postsecondary system because they also provide what would be the last year of secondary school elsewhere. Theological schools were also excluded from these numbers, as they are more often than not associated with university. In the instances where institutions had multiple campuses, they were only counted once in our tally. One of the challenges in understanding and having an accurate picture of this sector is the varying terminology and institutional classification used by each provincial and territorial ministry responsible for postsecondary education.

\section{Websites}

Canadian Association of College and University Student Services (CACUSS), www.cacuss.ca

Canadian Association of University Teachers (CAUT), www.caut.ca

Universities Canada, www.univcan.ca

\section{References}

Allnutt, David E. (1985). A new coalition emerges. The Canadian Journal of Higher Education, 15(1), 1-10. URL: http://journals.sfu.ca/cjhe/index.php/cjhe/article/view/182951/182932 [July 15, 2018]. Andres, Lesley. (2009). Editor's introduction. The Canadian Journal of Higher Education, 39(3), 1. URL: http://journals.sfu.ca/cjhe/index.php/cjhe/article/view/525/573 [July 15, 2018].

Bond, Sheryl L. (1987). Employment equity. The Canadian Journal of Higher Education, 17(2), 1-12. Carson, Scott A. (1999). Emberley on hot button politics in Canada's universities: A critique. The Canadian Journal of Higher Education, 29(2), 175-200. URL: http://journals.sfu.ca/cjhe/index.php /cjhe/article/view/183337/183293 [July 15, 2018].

Employment and Social Development Canada. (2017). List of designated educational institutions. URL: https://www.canada.ca/en/employment-social-development/programs/post-secondary/designated-schools.html [December 18, 2018].

Pidgeon, Michelle, Pullman, Ashley, Archer, Walter, \& Groleau, Amélie. (2019). The Canadian Journal of Higher Education/La Revue canadienne d'enseignement supérieur. Scholarly and Research Communication, 10(2): 1002305, 12 pp. 


\section{Scholarly and Research}

\section{Communication}

VOLUME 10 / ISSUE 2 / 2019
Ferris, Peter. (1989). Post-secondary education in Northern Canada. The Canadian Journal of Higher Education, 19(1), 1-9.

Henry, Frances, James, Carl, Li, Peter S., Kobayashi, Audrey, Smith, Malinda S., Ramos, Howard, \& Enakshi, Dua (2017). The equity myth: Racialization and Indigenity at Canadian universities. Vancouver, BC: UBC Press.

Jones, Glen A. (2012). Reflections on the evolution of higher education as a field of study in Canada. Higher Education Research \& Development, 31(5), 711-722. doi: https://doi.org/10.1080/07294360 .2012 .714747

Larivière, Vincent, Haustein, Stefanie, \& Mongeon, Philippe (2015). The oligopoly of academic publishers in the digital era. PloS One, 10(6), 1-15. URL: https://journals.plos.org/plosone/article?id $=10.1371$ /journal.pone [July 15, 2018].

Michaud, Lucien F. (1973). Editorial. The Canadian Journal of Higher Education, 4(1), 1-5.

Monahan, Edward J. (1971). Editor's introduction. The Canadian Journal of Higher Education, 1(1), 1-3.

Pascal, Charles E. (2011). In the beginning: The founding of the CSSHE and its journal. Canadian Journal of Higher Education, 41(1), ii-iv.

Samad, D.R., Fraser, I.H., Fish, T.A., \& Fraser, L.D. (1995). Teaching excellence: A reaction to the Smith Commission Report and its effects. Canadian Journal of Higher Education, 25(1), 79-83. URL: http://journals.sfu.ca/cjhe/index.php/cjhe/article/view/183206/183171 [July 15, 2018].

Sheffield, Edward F. (1961). Population projection and the provision of community facilities: IV. Projecting university enrolment. Canadian Public Administration, 4(1), 113-116. URL: https://onlinelibrary.wiley.com/doi/abs/10.1111/j.1754-7121.1961.tboo411.x [July 15, 2018].

Sheehan, Nancy M. (1985). History of higher education in Canada. Canadian Journal of Higher Education, 15(1), 25-38. URL: http://journals.sfu.ca/cjhe/index.php/cjhe/article/viewFile /182953/182934 [July 15, 2018].

Tri-Agency. (2016). Tri-agency open access policy on publications. Ottawa, ON: Government of Canada. URL: http://www.science.gc.ca/eic/site/o63.nsf/eng/h_F6765465.html?OpenDocument [July 15, 2018].

West, Jevin D., Jacquet, Jennifer, King, Molly M., Correll, Shelley J., \& Bergstrom, Carl T. (2013). The role of gender in scholarly authorship. PloS One, 8(7), e66212. URL: https://journals.plos.org /plosone/article?id=10.1371/journal.pone.0066212 [July 15, 2018]. 